\title{
Accounting Comics as a Medium of Learning
}

\author{
Maria Maria ${ }^{1, *}$ Rosy Armaini ${ }^{1}$ Leni Noviyanti ${ }^{1}$ Yevi Dwitayanti ${ }^{1}$ \\ ${ }^{1}$ State Polytechnic of Sriwijaya, Indonesia \\ *Corresponding author email: mariamardjuki@ polsri.ac.id
}

\begin{abstract}
This study is research qualitative, to contribute to learning media development in SMK Negeri 1 Palembang. The multimedia is in the form of accounting comics with accounting cycle materials for class X. Comics are made in comic books and animated videos that can be accessed through web blogs. This research is a 4D model (Define, Design, Development, and Dissemination). The study was conducted from July to September 2021. Data collection was performed by monitoring, Q\&A, questionnaires, and validation of expert teams. Accounting comics was validated by the expert judges of many 20 people. The expert validation showed that: accounting comic learning media belongs to a very viable category and fits the criteria of media eligibility. Thus, accounting comic media can be piloted at a later stage and used for the accounting learning process.
\end{abstract}

Keywords: media of learning, accounting comics, multimedia.

\section{INTRODUCTION}

Covid 19 pandemic has brought a change from learning in class to an online class. Using effective and quality learning media becomes one of the efforts in realizing a fun and not boring learning atmosphere. The learning process in school is a fun activity, where students can interact with each other. However, some of these activities have now stopped. The use of online learning media takes students to understand teaching materials easily and unsaturated. One of the efforts that can be done is to use accounting comics on accounting learning. Comics in the form of cartoon images that describe characters in the story and provide entertainment to the reader. Reading comics can be done anytime and anywhere.

From the results of initial observations made on class $\mathrm{X}$ accounting learning at SMK Negeri 1 Palembang, learning still uses package books and problems/exercises in the book. Learning in that way tends to be monotonous and will cause students to get bored quickly. This prompted the research team to provide an alternative learning process using animated accounting comics that can be accessed through web blogs. Comics contain powerful visual elements and stories. Expression visualization invites the reader to be emotionally engaged so that the reader wants to continue reading until it is finished. This inspired the research team to choose material in comic form
Accounting comics in the form of accounting cycles are the products produced in this study.

In addition, using a web blog has advantages over other media, including ease of use and affordable cost. Web blogs are not heavy websites that require a lot of internet quotas. Therefore, learning using accounting comics in the form of animated videos via web blogs needs to be researched so that research results can be tested/acted upon in accounting learning

The learning process using accounting comics is expected to get a positive response from students. Students are expected to be enthusiastic in following the learning process. Using comics, get a fun learning atmosphere and information presented an easier to understand because of interesting presentation and blends elements of images, narratives, and animations. This is in line with research [1], comics are easy to understand because of their simplicity by combining images and text. Audio (animation) will provide something interesting for students. This is as revealed by [2] that somebody can learn better by combining images and writing. Comic, text-based content that's easy to understand, remember, and something fun [3]. It describes resources that can improve understanding especially to facilitate communication concerning education

Therefore, this study will develop comics as media of learning in the form of animation for online learning. Research issues are namely how to develop a learning 
media comic accounting that is suitable for use in the learning process.

\section{LITERATURE REVIEW}

\subsection{Learning Media}

Multimedia development is an innovative form in an educational environment [4]. According to the findings of [5], The Application of TAI learning models aided by a comic module can increase student outcomes in accounting. Comic learning [6] is effective in improving student learning outcomes. The use of caricatures has both positive and negative effects on a decision [7] : [8] .

\subsection{Comics}

The existence of comics has been since 1945, as a method that studies content and visual meaning [9]. Comics introduce dialogical reflexivity, integrative knowledge, and socializing [10] and as a means of knowledge communicating [11] [12]. [13], is one of the most significant elements associated [14] : [15] .

\subsection{Accounting Cycle}

The accounting cycle, something very important [16], tea loss is difficult for students.who are just studying financial accounting. The accounting cycle is the process of recording financial activities [17], in scope:

1) analyzing and measuring transactions

2) journaling transaction

3) posting

4) preparing a trial balance

5) preparing to adjust entry

6) preparing trial balance after adjusting

7) financial statements

8) closing entry

9) trial balance after closed

\section{METHODOLOGY}

\subsection{Research Stage}

The study took place in July - September 2021, aiming to develop the media of learning accounting comics on accounting cycle materials. The selection of research locations is based on several considerations:

- Problems faced and the availability of data needed.

- Analysis of needs respecting at learning.

- Availability of facilities and infrastructure, support the use of accounting comic learning media in the form of animated videos accessed through web blogs The research subject is class $\mathrm{X}$ students majoring in accounting SMK Negeri I Palembang.
The research begins with a preliminary study to explore the potential and identify problems that occur in the accounting learning process at vocational schools. Preliminary studies are conducted through the study of literature and information that support the importance of media in learning.

The research uses a 4-D model consisting of four steps: defines, design, development, dissemination [18] modified by [19] Define phase requires a valid, feasible, and efficient analysis of the needs and definitions of accounting comic media for learning media. The design stage consists of planning the development of an accounting comic that suits your needs. The development phase includes creating an animated video and validating accounting comics to experts in learning media (material experts and multimedia experts). The dissemination phase includes the determination of the accounting cycle material to be piloted. The research design is shown in figure 1.

Figure 1 The Frame of Mind Using Model 4D

\subsection{Data Collection and Analysis Techniques}

Data collection techniques through monitoring, Q\&A, questionnaires, and validation. Monitoring, Q\&A conducted to get direct information about accounting learning in school. Questionnaires are used to analyze

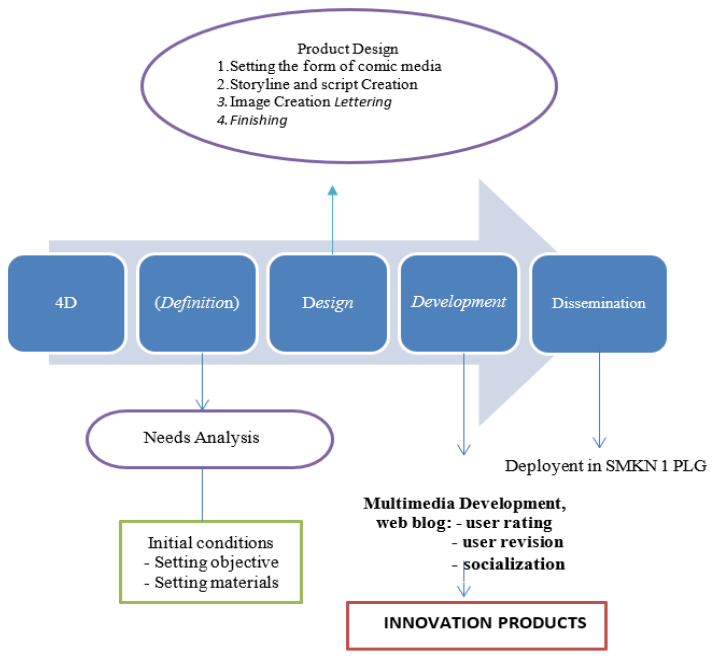

Figure 1 The Frame of Mind Using Model 4D

the needs of teachers and students, as a basis for consideration in developing the required learning media. Validation of media feasibility assessment consists of 10 media and 10 material experts (accounting teachers). Various suggestions and inputs from the teams of experts are used as the basis to improve the resulting media products. Data analysis techniques are qualitative descriptive analysis. Steps of analysis of comic eligibility data are carried out to change qualitative forms to quantitative as shown in Table 1. 
Table 1 Score Criteria

\begin{tabular}{|l|l|}
\hline very worthy & 5 \\
\hline proper & 4 \\
\hline enough & 3 \\
\hline Less worthy & 2 \\
\hline very less worthy & 1 \\
\hline
\end{tabular}

Calculates average score with:

$\overline{\mathrm{X}}=\frac{\sum x}{N}$

Information:

$\overline{\mathrm{x}}=$ average value

$\sum x=$ total value

$N=$ total appraiser

Then, an average score is changed into five categories. very worthy (A), proper (B), enough (C), less (D), and very less worthy (E). Table 2 shows the ideal assessment criteria

Table 2 Ideal Score

\begin{tabular}{|l|l|l|}
\hline Nilai & Score Range & Categorie \\
\hline A & $\mathrm{X}>4,01$ & Very worthy \\
\hline B & $3,34<\mathrm{X} \leq 4,01$ & proper \\
\hline C & $2,67<\mathrm{X} \leq 3,34$ & enough \\
\hline D & $2,00<\mathrm{X} \leq 2,67$ & less \\
\hline E & $\mathrm{X} \leq 2,00$ & Very less worthy \\
\hline
\end{tabular}

\section{RESULTS AND DISCUSSION}

\section{1. Preliminary Study on Needs Analysis}

Comics are one of the media teaching and learning activities in the pandemic period. As revealed, [20] comics respond to pandemics /disasters, an interesting study conducts comics such as interesting source material. Comics as an integral part of the research process, there has been an increase [21].

Figures The results of observation and interviews in obtaining information on accounting learning in school have been going well. However, there are still obstacles to the use of learning media (rarely done). Using of technology-based learning media in the learning process is limited to certain materials. Analysis of teachers' needs shows, the use of learning media and utilization in the classroom in accounting learning number $70 \%$, and $70 \%$ of teachers expressed difficulties in developing accounting learning media, while $85 \%$ of teachers agreed to develop comic media in accounting learning.

\subsection{Product Design}

Things to do in preparing the initial product design of media, namely establishing basic competencies to be developed in media comics accounting. In this study, the basic competencies chosen are the accounting cycle. Comic media content discusses material ranging from recording transactions to compiling financial statements. The material is presented in an animated video consisting of: first, an introduction that presents information about the transaction recording process. Second, the accounting comic presented the process of preparing financial statements. Third, drill and practice that displays questions /questions about the exercise. Pre-determined media content becomes a guideline for the research team in creating flowchart charts and compiling a storyboard accounting comic. quantitative as shown in Table 1.

Some of the applications used in developing the media of accounting comics are:

1. Adobe Illustrator is used for editing and images of characters and characters that will be included in the accounting comics to be developed.

2. Adobe Audacity is used to edit the voice used in animated videos.

3. Adobe After Effect is used to create animated videos by combining multiple images and sounds that have been created before.

4. Adobe Media Encoder is used to perform rendering that works so that the video can be stored in the form of a video such as mp4.

Figures 2 to figure 5 are part of the resulting accounting comics.

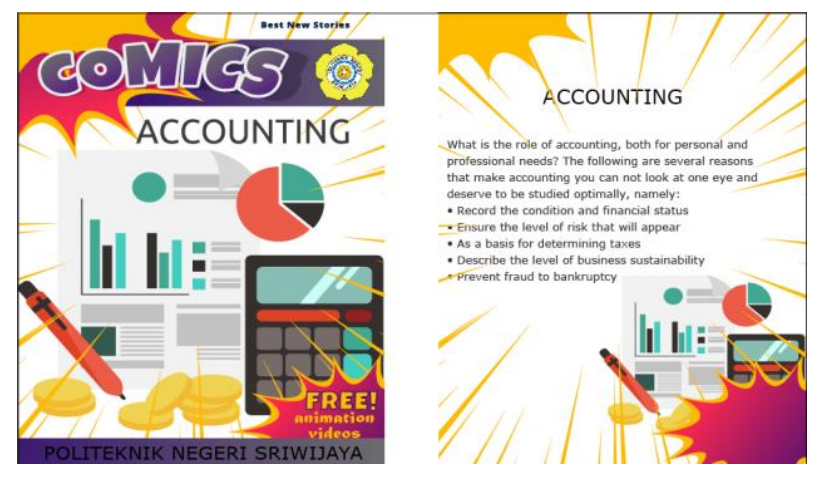

Figure 2 Accounting Comics (Introduction section) 


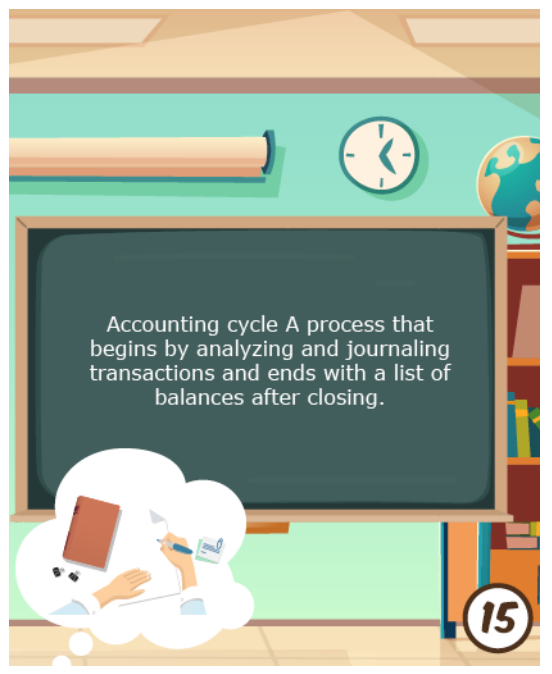

Figure 3 Introduction Section of Accounting Comics

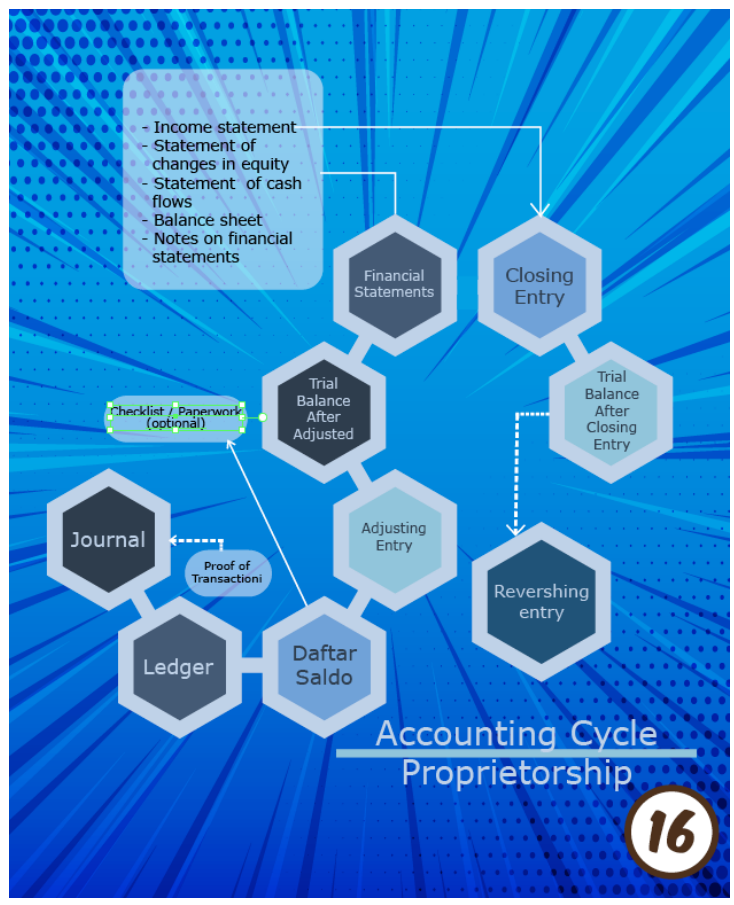

Figure 4 Accounting Cycle

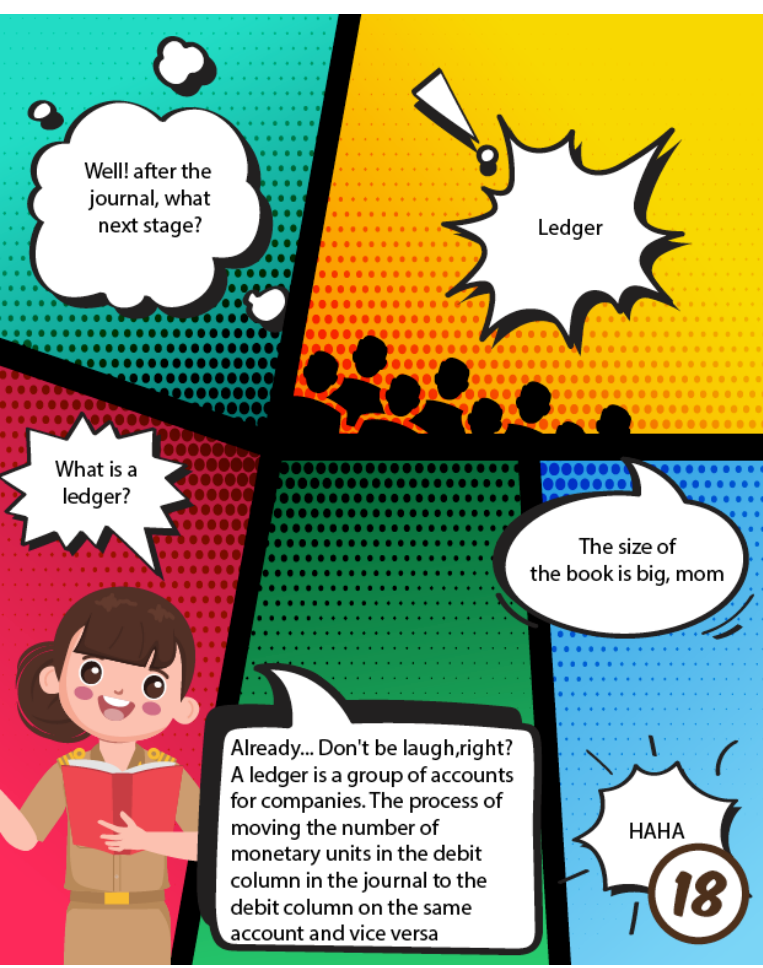

Figure 5 Accounting Comics Story Section

\subsection{Analysis Results}

The results of validation by a team of experts that have been done, namely:

a. Material Experts

Aspects of the material assessed include aspects of accounting content/materials and aspects of usefulness. The results of material expert, material quality assessment score was obtained 3.99, usefulness aspect was 4.05. The result value of material media is based on expert assessment of material as shown in table 3.

Table 3 Material Expert Validation

\begin{tabular}{|l|c|c|c|l|}
\hline No & Aspect & $\begin{array}{c}\text { Average } \\
\text { Score }\end{array}$ & $\begin{array}{c}\text { Qualitative } \\
\text { Value }\end{array}$ & Category \\
\hline 1 & $\begin{array}{l}\text { Material } \\
\text { Quality }\end{array}$ & 3.99 & B & Proper \\
\hline 2 & Benefits & 4.05 & A & $\begin{array}{l}\text { Very } \\
\text { Worthy }\end{array}$ \\
\hline $\begin{array}{l}\text { An average } \\
\text { number of } \\
\text { scores }\end{array}$ & 8.04 & A & $\begin{array}{l}\text { Very } \\
\text { Worthy }\end{array}$ \\
\hline $\begin{array}{l}\text { An average } \\
\text { score per } \\
\text { aspect }\end{array}$ & 4.02 & A & $\begin{array}{l}\text { Very } \\
\text { Worthy }\end{array}$ \\
\hline
\end{tabular}

Source: primary data processed (2021) 


\section{b. Media Experts}

The media aspects assessed include book cover design, content layout, typography, and illustration. The results of the assessment of the feasibility of accounting comic media by media experts (Table 4). It is known that the cover aspect of the book obtained a score of 4.03, the layout aspect of the content 4.00, the typographic aspect 3.90, the typographic aspect 4.05, the illustration aspect 4.50. The qualitative value of media is based on the expert assessment of the media as shown in table 4.

The overall validation of expert judgment based on table 3 and table 4, obtained an average score of 4.07, thus, the accounting comic learning media is categorized as very "worthy" both based on media eligibility criteria.

Table 4 Media Expert Validation

\begin{tabular}{|l|l|c|c|c|}
\hline No & Aspects & $\begin{array}{c}\text { Average } \\
\text { score }\end{array}$ & $\begin{array}{c}\text { Qualitative } \\
\text { Value }\end{array}$ & Category \\
\hline 1. & $\begin{array}{l}\text { Book } \\
\text { cover } \\
\text { design }\end{array}$ & 4.03 & $\mathrm{~A}$ & $\begin{array}{c}\text { very } \\
\text { worthy }\end{array}$ \\
\hline 2. & $\begin{array}{l}\text { Content } \\
\text { layout }\end{array}$ & 4.00 & $\mathrm{~B}$ & proper \\
\hline 3. & $\begin{array}{l}\text { Typo } \\
\text { graphy }\end{array}$ & 3.90 & $\mathrm{~B}$ & proper \\
\hline No & Aspects & $\begin{array}{l}\text { Average } \\
\text { score }\end{array}$ & $\begin{array}{l}\text { Qualitative } \\
\text { Value }\end{array}$ & Category \\
\hline 4. & $\begin{array}{l}\text { Illustrat } \\
\text { ion }\end{array}$ & 4.33 & A & $\begin{array}{l}\text { very } \\
\text { worthy }\end{array}$ \\
\hline $\begin{array}{l}\text { An average } \\
\text { number of } \\
\text { scores }\end{array}$ & 16.26 & A & $\begin{array}{l}\text { very } \\
\text { worthy }\end{array}$ \\
\hline $\begin{array}{l}\text { An average } \\
\text { score per } \\
\text { aspect }\end{array}$ & 4.07 & A & $\begin{array}{l}\text { very } \\
\text { worthy }\end{array}$ \\
\hline
\end{tabular}

Source: primary data processed (2021)

\section{CONCLUSION}

Accounting learning development in the form of comics on accounting cycle materials for students of SMK Negeri I Palembang is an innovative learning medium. The development of comics through four steps, define (defining), design (designing), develop (development), dissemination (spread). Accounting comics are very worthy of use in the learning process. This result is the same as validation by a team of experts (expert judgment): material experts and media experts.

\section{AUTHORS' CONTRIBUTIONS}

Maria Maria: conceptualization, methodology, formal analysis, writing - review \& editing. Rosy Armaini: data curation, investigation, writing - review \& editing. Leni Novianti: animation, software, writing - review \& editing. Yevi Dwitayanti: validation, writing review \& editing.

\section{ACKNOWLEDGMENTS}

We thank the Sriwijaya State Polytechnic agency for the research of this article.

\section{REFERENCES}

[1] Christensen, M., \& Sébastien Rocher. (2020). The Persistence Of Accountant Beancounter Images In Popular Culture. Accounting, Auditing and Accountability Journal, 33(6), 1395-1422. https://doi.org/10.1108/AAAJ-09-2019-4163

[2] Wankel, L. A., \& Patrick Blessinger. (2013). Inventive Approaches in Higher Education: An Introduction to Using Multimedia Technologies in Increasing Student Engagement and Retention Using Multimedia Technologies: Video Annotation, Multimedia Applications, Video Conferencing, and Transmedia Storytell. CuttingEdge Technologies in Higher Education, 6(F), 316.

[3] Cilein Kearns, Nethmi Kearns , Irene Braithwaite, Nick Shortt, Allie Eathorne ,Alex Semprini, and Richard Beasley.(2021). Using comics and curiosity to drive pandemic research on a national scale. Journal of Visual Communication in Medicine 44(1), pp. 12-22.

[4] Ichsan, I. Z., Agung Purwanto, \& Henita Rahmayanti. (2021). E-learning In New Normal Covid-19 Era: Measure Hots and ProEnvironmental Behavior About Environmental Pollution. International Journal of Evaluation and Research in Education (IJERE), 10(3), 790-797. https://doi.org/10.11591/ijere.v10i3.21382

[5] Sianturi, C. H., Jaryanto, \& Sohidin. (2018). Peningkatan Hasil Belajar Akuntansi Melalui Penerapan Model Pembelajaran Team Assisted Individualized (TAI) Berbantuan Modul Komik Pada Siswa SMK Surakarta. Jurnal "Tata Arta" UNS, 4(3), 1-9.

[6] Antonius,Mahsudi Mashudi, \& Endang Purwaningsih. (2019). Pengembangan Pembelajaran Akuntansi Melalui Media Komik di SMK Katolik Santa Maria Pontianak. Proceedings International Conference on Teaching and Education (ICoTE), 2(2), 280-287.

[7] Smith, M., \& Richard Taffler. (1996). Improving 
The Communication of Accounting Information Through Cartoon Graphics. Accounting, Auditing \& Accountability Journal, 9(2).

[8] Davison, J. (2015). Visualizing Accounting: An Interdisciplinary Review and Synthesis. Accounting and Business Research, 45(2), 121165.

https://doi.org/10.1080/00014788.2014.987203

[9] Davison, J. (2009). Icon, Iconography, Iconology: Visual Branding, Banking and The Case of The Bowler-Hat. Accounting, Auditing and Accountability Journal, 22(6), 883-906. https://doi.org/10.1108/09513570910980454

[10] Goltz, D. B. (2011). Frustrating The "I": Critical Dialogic Reflexivity With Personal Voice. Text and Performance Quarterly, 31(4), 386-405. https://doi.org/10.1080/10462937.2011.602707

[11] M. Tatalovic,(2009) "Science Comics As Tools For Science Education and Communication: A Brief, Exploratory Study, ” J. Sci. Commun., vol. 8, no. 4, pp. 1-17, 2009

[12] S. Ogier and K. Ghosh, (2017) "Exploring student teachers' capacity for creativity through the interdisciplinary use of comics in the primary classroom.," J. Graph. Nov. Comics, pp. 1-17, 2017.

[13] C. Matuk, T. Hurwich, A. Spiegel, and J. Diamond,(2021) "How Do Teachers Use Comics to Promote Engagement, Equity, and Diversity in Science Classrooms?," Res. Sci. Educ., vol. 51, no. 3, pp. 685-732, 2021, doi: 10.1007/s11165-0189814-8.

[14] Egan, A. (2014). There's Something Funny About Comedy: A Case Study in Faultless Disagreement.
Erkenntnis, 79(SUPPL.1), 73-100. https://doi.org/10.1007/s10670-013-9446-3

[15] Francis, M., \& Hal Foster. (2010). Pop. London: Phaidon Press.

[16] Zhang, T., Lay-Chin Low, \& Poh-Sun Seow. (2020). Using Online Tutorials to Teach The Accounting Cycle. Journal of Education for Business, 95(4), 263-274. https://doi.org/10.1080/08832323.2019.1636755

[17] Ebrahim, N. A. E.-R. (2020). The Impact of Internet of Things on Accounting Cycle. الفكر 24(3), 209-109. https://doi.org/10.21608/atasu.2020.113289.

[18] Thiagarajan, S., Dorothy D. Semmel, \& Melvyn I. Semmel. (1974). Instructional Development for Training Teachers of Exceptional Children. Minneapolis, MN: University of Minnesota.

[19] Istiyono, E., Wipsar Sunu Brams Dwandaru, Risky Setiawan, \& Intan Megawati. (2020). Developing of Computerized Adaptive Testing to Measure Physics Higher Order Thinking Skills of Senior High School Students and Its Feasibility of Use. European Journal of Educational Research, 9(1), 91-101. https://doi.org/10.12973/eu-jer.9.1.91

[20] S. Saji, S. Venkatesan, and B. Callender, "Comics in the Time of a Pan(dem)ic: COVID-19, Graphic Medicine, and Metaphors," Perspect. Biol. Med., vol. 64, pp. 136-154, 2021.

[21] P. J. Kuttner, M. B. Weaver-Hightower, and N. Sousanis, (2021) "Comics-based research: The affordances of comics for research across disciplines," Qual. Res., vol. 21, no. 2, pp. 195214, 2021, doi: 10.1177/1468794120918845. 